Proceedings of FIKUSZ '16 Symposium for Young Researchers, 2016, 151-159 pp ๔ The Author(s). Conference Proceedings compilation (c) Obuda University Keleti Faculty of Business and Management 2016. Published by Óbuda University http://kgk.uni-obuda.hu/fikusz

\title{
What about Change? An Old Theory in a New Light.
}

\author{
Torda Tamás \& Tordai Zita
}

tamas.torda@yahoo.com

\begin{abstract}
Change is a constant part of our life... It is almost a klisé. It is everywhere, and we should know, how can it happen to us, and how to act it. This article is the first part of a year-long study, that aims to find, which factors can be a part of a successful lifestyle change, especially for conscious consuption. We consume ridiculously much, way over the level, we need. Half of the world is hunger, and the other half is trying to lose some weight. If we can create a model, like an equation f.e. Two times self confidence and one part good family backgorung equals ten percent succes lifetime change, whicth is probably not, but if we can found something like that, it would change the theory of lifestyle changing in modern consuption society. This article shows our lifetslye changing model theory, and a study, which presents, it's appearance in practise.
\end{abstract}

Lifestyle changes, conscious consumption factors, decision making

\section{The model's theory}

Changing is difficult, because the brain essentially would like to be in the most energy-efficient state. This can be achieved if the brain reduces the number of external and internal factors to the state of the minimum. This also implies that the brain try to avoid the unnecessary innovations, so stick to the old habits, which means that brain likes to do everything on the same way. (Kahneman, 2012) This leads to habits. This is practically equivalent to the comfort zone, which is a physical "space bubble" and if other people are "penetrating" into this, it felt uncomfortable. (Pease, 2000) All of this must be added the discovery of Charles (Duhigg, 2012), that a habit has its phases. At first, the brain receives a signal then the routine starts which is followed by the reward. After a short time the signal is appeared again and the usual loop has closed. With enough repetition of these mechanisms are become automatic after a while. (Duhigg, 2012) If change in habits are wanted it should be awared, to be controlled them with decisions. (Dr. Velencei, 2013)

First, the difference between data, information and knowledge is necessary to separate. The data is a detected effect, but it does not include any meaning for us. 
When this data is interpreted in some aspect, it becomes information. Knowledge has been confirmed by a true belief, it already has value. (Davenport - Prusak, 2001) "Heterogeneous and constantly changing mix of experiences, values and associated information." Knowledge is complex, its roots cannot be expressed verbally. The Commissioner's conviction is usually a mistake, because it excludes the unknown we do not know. (Szeghegyi, 2011, page 61). In addition, other factors can distort the perception of reality. These are the filters which are based on our own experiences, which is called selective perception; what is more, the settlement schemes, stereotypes, Halo-effect and the searching of causality can be also an influencing factor. The cognitive dissonance is when an internal event contradicts the intrinsic value of the system, and in this way the contradiction appears. (Zoltayné Pepper, 2005)

\subsection{The combined changing modell theory}

The main component of my changing-model's research has been recognised in psychology, the trans-theoretical model. (Prochaska, et al., 2009) It is important to note that this model is already 30 years old, and although it is constantly being researched, the original scheme is still the most popular, if not the only changingmodel that is universally applicable to all kinds of changes. The model has been successfully applied to quitting smoking and other diseases, or in combination with several changes of behavior, coaching and other programs over the decades. (Pro-change behavior, Systems, inc., 2016) The model itself consists of six phases.

- Pre-Contemplation: This section of the main features that we are not aware of the change we need. What we do not see, but the environment has been detected and often will also get to let us know.

- Contemplation: At this stage we recognized the problem and brings us want to change. However, so far we cannot talk about Engagement or doable activation. At this stage, we know which way they should go, but we do not know how to start, or just do not know what to do, but we want to do something.

- Decision: This is not necessarily a long period but it is important for the floor plan the house is to be built. Of course, it is necessary also decided that we will do well after the preparation

- Active change: This is where changes are developed and made by act.

- Maintance: At this stage, we have achieved successes, and the wanted state is no longer as far away as the early phase of the action. However, there are throw-backs. There are rarely manage to keep the change for the first time. Therefore, needs a plan that can be followed.

- Relapse: This change is most coveted stage. When the new habit entrenched when the new behavior has been self-sustaining. There is disagreement about the part that it cannot be clearly defined by this point, which would be universally valid for everyone. 
These are the steps, but not every single one will be reached by during the change. There are throw -backs, and each step can be a possible entering or exiting point. These steps are paradigms which means second order changes and every paradigms are contains first-order changes too. It is important to note that this is a spiral phase, so stage one of the road leads to another non-linear, and not necessarily only upward. The other model is based on the group theory, which is a framework that describes the change within the system, while the system itself is unchanged. The logical types theory provides a framework that is how the relationship between the class and the member of it, and pictures of the transformation when a class entering from one level to another higher logical one. From this arises two types of change. The first order change describes changes in one system while the system is permanent, such as the Matrix. Movie, when the actors do whatever you can, within the matrix, but you are connected to the machine. The second order change was when Neo disconnected from the machine or in this chase, take a different paradigm, and this is dramatically change. Sometimes, this change may seem illogical, because it is there in one moment and the next, there is not. The second order change, is the changing of change. (Watzlawick, et al., 1990)

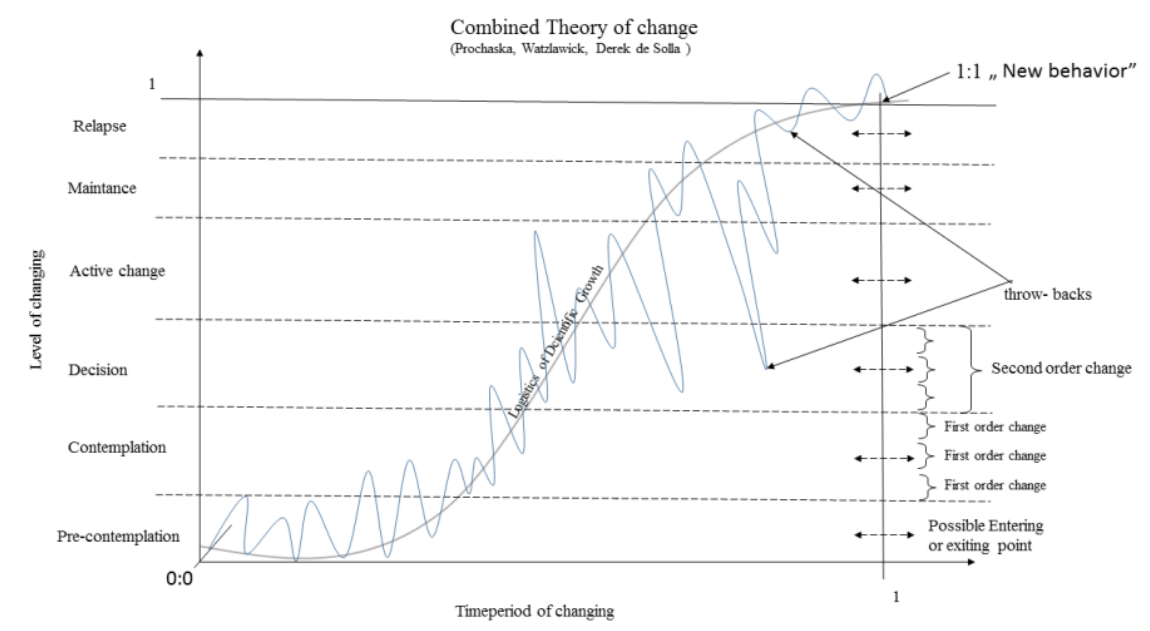

Figure 1.

Combined Theory of change by Prochaska and Watzlawick

In Figure 1, three changing models have combined. The Prochaska one's (Prochaska et al., 2009) and the Watzlawick one's are used for describing people' behaviors. (Watzlawick et al., 1990) The third one is Derek de Solla's (Price, Derek DeSolla 1979) logistics development theory. The process of chang is represented by the blue line. It it followed the graph by convergent oscillation, if mayor throw-backs have not become. Every stages can be possible entering or exiting points. Every new stages, like Contamplation, or Relapse, are paradigms. A paradigm shift has seen, in allocations indicate, while first order change can 
talked about minor changes within the logical paradigms, which are second order changes. (Watzlawick) What is even more, Kurzweil's singularity theory (Kurzweil, 2013) can not be contradicted, it is just investigates a much minor scale.

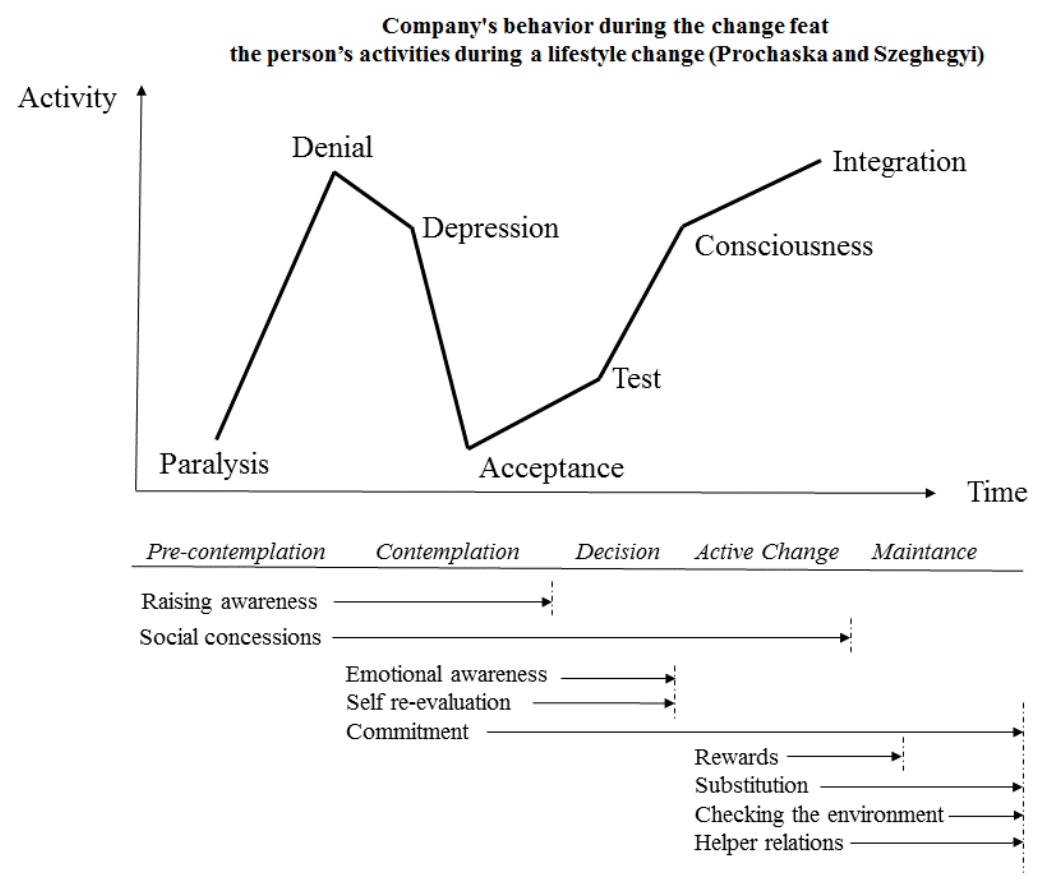

Figure 2.

Company's behavior during the change feat the person's activities during a lifestyle change (by Prochaska, Szeghegyi)

In Figure 2, there is relation because the change in the company life's process (Szeghegyi, 2011), which consists of two participation waves. A negative one to that is a denial and a positive to that is through raising awareness of the integration culminates. If we compare this with the events described in Prochaska's (Prochaska et al., 2009) model, what happens to the individual during the change seems to conspicuous the parallel. The denial can be solved with raising awareness of long displayed a willingness to test, and then with self-re-evaluation, commitment and using rewards can the change takes to the maintance by integration. To do so helper relations, and substitutions, and the checking the environment can be very helpful to facilitate the process. Another parallel is that consideration, is a passive state what is well illustrated in the company's first reaction to change, Paralysis. 


\section{Primary research}

During the preliminary research on the subject similar survey was not found. Questionnaire survey forms were researched.The Hungarian sample counts 133. For the research it is an important pillar to test the change model. For this we thought factor analysis the best method to find out how respondents feel about these change stages has been on above-mentioned (pre-contemplation stage, contemplation stage etc). In order to investigate this, a list of 56 statements were created, and were evaluated in a five-scale Likert scale by the subjects, where 1 meant "Absolutely NOT typical," and 5 was "Absolutely typical" (Dr. Fabian, 2014) The Kaiser-Meyer-Olkin criterion of KMO are of very great range, because the value is above 0.8 . This means that the items of inadequate factor. (See Table 1). The Bartlett test is successful, because the Sig. less than 0.05, that there is a correlation between the initial claims. (Sajtos \& Mitev, 2007)

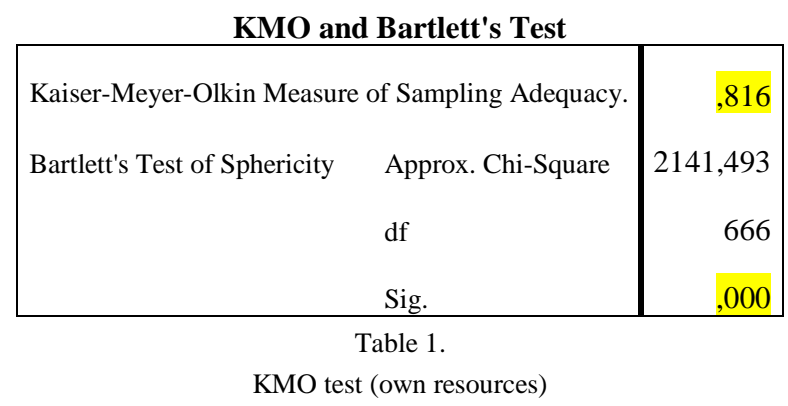

The reliability test (Cronbach's Alpha) also brought good results. (Table 1) of the examined claims consistency of 0.886 ( 0.8 over longer a very good), while to the piece related standardized value is 0.884 . In total, this means that the statements and answers are also suitable for factor analysis. Table 2 shows that the respondents (those who experienced or planned changes in their lives) the allegations we have listed their answers into what factors can be grouped. The specific analysis is shown in Table 3

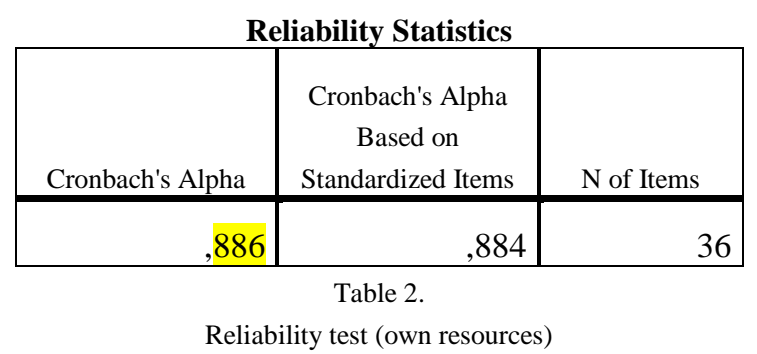


Rotated Component Matrix ${ }^{\mathrm{a}}$

\begin{tabular}{|c|c|c|c|c|c|}
\hline & & & Sompor & & \\
\hline & 1 & 2 & 3 & 4 & 5 \\
\hline (Dec) I have decided, that I will change my lifestyle. & ,81 & ,16 & 191 &,- 091 & 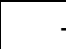 \\
\hline (Act) It is easy to talk about changing, I make the change. & ,74 & - & ,219 &,- 056 & , 108 \\
\hline (Dec) I want to act, no matter what it takes. & ,71 & - & ,055 &,- 107 & ,151 \\
\hline (Rel) I feel better myself since I have made the change on & ,70 & - & 341 & 096 & 063 \\
\hline (Dec) I have made a plan for this changing. & ,69 &, 04 &,- 215 & ,027 &, 151 \\
\hline (Cont) I have thought that I have to change my life/habits. & ,68 & ,23 & ,289 &,- 057 & - \\
\hline (Maint) I have a plan after I managed to reach the & ,64 & - & 010 &,- 018 & 145 \\
\hline (Maint) I have made a change not only on one habit, but & ,64 & - &, 076 & ,066 & ,064 \\
\hline (Act) I think about what would be the results of the acts for & ,62 & - & ,183 & 079 & ,334 \\
\hline (Rel) I am proud that I have made a change on one of my &, 60 & - &, 508 & 104 & 036 \\
\hline (Act) In the past few weeks everyday I have been doing &, 60 & - & , 121 & 188 & 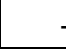 \\
\hline (Dec) I know exactly how I will be after the changing. &, 58 & 00 &,- 051 & ,375 & 206 \\
\hline (Dec) I was thinking about what I would like to be and &, 58 & - & ,230 & ,076 & - \\
\hline (Act) Changing can be reached by an immediate action. &, 57 &, 12 & ,271 &,- 047 & - \\
\hline (Dec) I am determined by the changing and nothing can &, 56 & - & ,086 & 182 & . \\
\hline (Maint) I try to avoid everything which is connected with &, 50 & - &,- 030 & ,216 &, 010 \\
\hline (Pre-Cont) Just others can change easily. & - &, 70 &,- 087 & ,202 &, 100 \\
\hline (Maint) If I managed to reach the changing, I can lay back & - & ,64 &,- 007 &,- 059 &, 121 \\
\hline (Bef) I am afraid that I will be again like I was before the & - &, 60 & 047 & ,202 &, 010 \\
\hline (Pre-Cont) I would like to change something in my life, but & - &, 53 & ,284 & 169 & 014 \\
\hline (Cont) As soon as I will be ready, the changing will be &, 01 & 05 & ,709 & ,039 &, 184 \\
\hline (Maint) I pay attention to not flipping back to the state of &, 47 & - &, 511 & ,220 & - \\
\hline (Act) Changing $=I$ doing something important instead of &, 19 & - & 076 &, 556 & 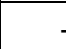 \\
\hline (Rel) I thought if I solve a problem, I can get rid of it &, 14 &, 45 &, 114 &, 506 & 039 \\
\hline (Dec) I tell my plans everybody. & ,26 &, 41 &,- 058 &,- 057 & ,670 \\
\hline (Dec) I tell my friends what I will do. & ,26 &, 04 & ,289 &,- 021 & ,643 \\
\hline (Act) If I am in a hard situation, I ask for help easily. &, 10 & - & ,322 & 129 &, 561 \\
\hline
\end{tabular}

Extraction Method: Principal Component Analysis.

a. Rotation converged in 13 iterations.

(Pre-Cont=Pre-Contemplation, Cont=Contemplation, Dec=Decision, Act=Active change,

Maint=Maintance,Rel=Relapse )

Table 3.

Factor Analysis of Change in Claims (own resources)

For the factor analysis, Varimax rotation is used, which is looking for a very highly or non correlating variable pairs. This is the most stable and the best factoring separation method, the program knows. Also, it is important to note that because the sample including 133 people, weight factor should be applied, which 
means that 0.50 or less weight statements are not typical of the explanations given to factors such as a clearer interpretation, they must be removed. (Sajtos \& Mitev, 2007) In the analysis, we found five factors that order of magnitude follow such as:

[1.] Active Change and Activity based prepairing

[2.] Contenplation

[3.] Maintance

[4.] Activity based maintance

[5.] Decision

The six-stage model we set 4 was finally found in the analysis, which means that in practice it works, the theory. What is interesting is that even though the various other allegations were meant to be for other stages, and yet the meaning of the respondents also became the grouping relevant sense. Finally, the model we developed a phase 6 , which is hidden in the four phases 5 and 6 because they supposed to act based on the preparation (whitch we called Activity based prepairing) and the act in maintaining (we called: Activity based maintance) a two-section section. Our hypothesis is, that the transitions are not clearly separated, because being changed is not easy, and there is time has to passed, for the commitment has made, and self re-evaluation has to be done. Entering each paradigm has needed time. They cannot entered to one phase to another, they needed, some kind of preparation, which is both times activity based. This is illustrated in Figure 3. This fact suggests that this model is suitable for use and can be adapted for further research.

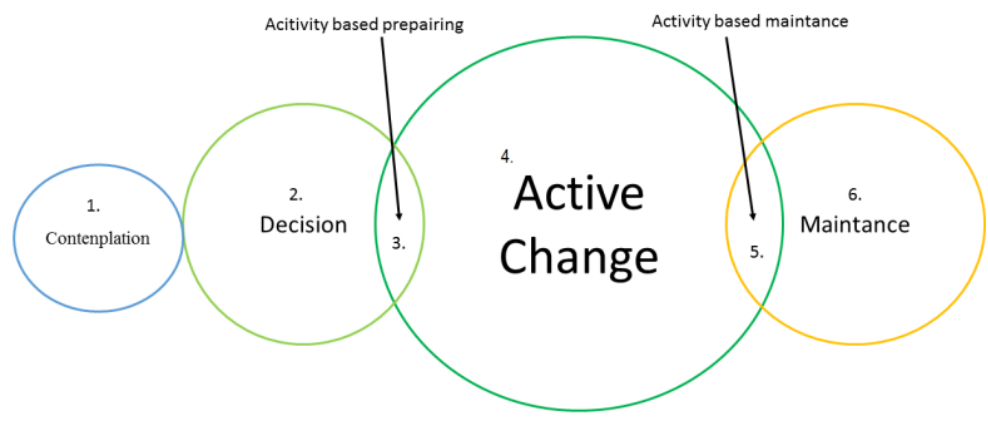

Direction of the desired change

Figure 3.

Changing factors in practise (own source) 


\section{Conclusions}

However consumption chioses' connections had not expanded in this article, some older research of ours suggested that there might have connection, like in conscious communication. (Torda T. 2015) But that connection cannot be explored without a usable change model which works in practise.

The paper set up a theoretical model in which the pre-contemplation, you can reach the relapse throw contemplation, decision, active change and maintance stages. The purpose of this work was to justifie these theoretical stages, which hard to separate in practice sections, which can also successfully completed. However, there is difference between theory and practice, that the respondents action-oriented factors have been identified. The contemplation stages, followed by a decision phase, which followed by an activity-based prepairing, active change and an activity-based maintenance, which finally ends the maintance.(Figure 3) The comparison shows that the sections can be adapted. However pre-contemplation and relapse, can not be measured directly. It is not surprising, becasue if those, who do not know that, they would need to change, cannot asked them for what they need to change. And the stage for the relapse is not defined in usual for the changes.

\section{Acknowledgement}

This article based on Torda T. [2016] CONSCIOUS CONSUMPTION BACKGROUND FACTORS IN THE LIGHT OF THE LIFESTYLES I.

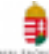

SupPorted BY THE ÚNKP-16-2/I. New National ExCEllence Program of THE MinisTRY OF HuMAN CAPACITIES

\section{References}

[1] Davenport, T. H. \& Prusak, I., 2001. Tudásmenedzsment. Budapest: Kossuth.

[2] Dr. Fábián, G., 2014. Alkalmazott kutatás módszertan, Debrecen: Debreceni Egyetem Egészségügyi Kar.

[3] Dr. Velencei, J., 2013. Üzleti döntések támogatása. Budapest: Óbudai Egyetem.

[4] Duhigg, C., 2012. A szokás hatalma. Budapest: Casparus Kiadó Kft.

[5] Hong, H., Kubik, J. D. \& Stein, J. C., 2004. Social Interaction and StockMarket Participation. Journal of Finance, 59(1), pp. 137-163. 
[6] Kahneman, D., 2012. Gyors és lassú gondolkodás. Budapest: HVG kiadó.

[7] Kehl, D., 2012. Mintaelemszám tervezés Likert-skálás lekérdezések esetén klasszikus és bayesi keretek között, Pécs: Gazdálkodástani Doktori Iskola.

[8] Kiss, M., 2015. Alapmarketing. hely nélk.:Akadémiai Kiadó.

[9] Kurzweil, R., 2013. The Singularity Is Near. Budapest: Ad Astra.

[10] McConnaughy, E. A., Prochaska, J. O. \& Velicer, W. F., 1983. Stages of Change in Psychotherapy. Psychotherapy: Thory, research and practise, 20(3), pp. 368-375.

[11] Németh, R. \& Simon, D., 2011. Társadalomstatisztika, TÁMOP 4.2.5 Pályázat könyvei: Digitális Tankönyvtár.

[12] Pease, A., 2000. Testbeszéd - Gondolatolvasás gesztusokból. 15 szerk. Budapest: Park.

[13] Price, Derek DeSolla: Kis tudomány - nagy tudomány, Akadémiai Kiadó, Budapest, 1979.

[14] Pro-change behavior, systems, inc., 2016. The Transtheoretical Model. [Online]

Available at: http://www.prochange.com/transtheoretical-model-ofbehavior-change [Hozzáférés dátuma: 0611 2016].

[15] Prochaska, J. O., Norcross, J. C. \& DiClemente, C. C., 2009. Valódi újrakezdés. Budapest: Ursus Libris.

[16] Sajtos, L. \& Mitev, A., 2007. SPSS kutatási és adatelemzési kézikönyv. Budapest: Alinea.

[17] Szeghegyi, Á., 2011. Tudásmenedzsment I. (elektronikus jegyzet ), Budapest: Óbudai Egyetem.

[18] Torda T., 2015: MORE CONSCIOUS COMMUNICATION MAKE YOU HAPPIER?

[19] Torda T., 2016: CONSCIOUS CONSUMPTION BACKGROUND FACTORS IN THE LIGHT OF THE LIFESTYLES I.

[20] Watzlawick, P., Weakland, J. H. \& Fisch, R., 1990. Változás, A problémákkeletkezésének és megoldásának elvei. Budapest: Gondolat.

[21] Zoltayné Paprika, Z., 2005. Döntéselmélet. Budapest: Alinea 